\title{
Breastfeeding as a Time-Varying- Time-Dependent Factor for Birth Spacing: Multivariate Models with Validations and Predictions
}

\author{
Rajvir Singh PhD, Hamad Medical Corporation (HMC), Cardiology \& Cardiothoracic \\ Research Centre, CCS Department, Doha, Qatar \\ Vrijesh Tripathi PhD, Department of Mathematics \& Statistics, The University of the West \\ Indies, Trinidad \& Tobago, West Indies
}

Kalpana Singh MSc, Clinical Research Department, Max Healthcare Institute Ltd., New Delhi, India

Rajesh Kumar Ahuja MSc, Department of Biostatistics, All India Institute of Medical Sciences, New Delhi, India

Mani Kalai Vani MSc, Department of Biostatistics, All India Institute of Medical Sciences, New Delhi, India

Sada Nand Dwivedi PhD, Department of Biostatistics, All India Institute of Medical Sciences, New Delhi, India

Correspondence may be directed to: Sada Nand Dwivedi, Department of Biostatistics, All India Institute of Medical Sciences (AlIMS), New Delhi-110029, India, Tel: +91-11-2659-3387, E-mail: dwivedi7@gmail.com.

\footnotetext{
Abstract

Data used in the present study are from the National Family Health Survey (NFHS-I) 1992-93 (International Institute for Population Sciences 1995), India. Our study has developed Cox model analyses to see the effect of breastfeeding as a time-varying and time-dependent factor on birth spacing. While it is acknowledged that breastfeeding has a protective effect on birth spacing, such analysis of breastfeeding allows for a more nuanced understanding of that effect. Multivariate analysis revealed that breastfeeding, ever experience of fetal loss, education of women, employment status of women, education of husband, media exposure, survival status of index child and place of residence played an important part in extending birth space in at least one of the birth-spacing intervals (first to fifth). However, the variables varied from the first birth spacing to the fifth birth spacing. Breastfeeding is the only covariate found to be a significant protective factor associated with each birth spacing. Furthermore, this study validates the developed models with their prediction utilities for birth spacing.
} 


\section{Introduction}

Birth spacing/birth interval has been identified as an important component of reproductive health leading to many known documented benefits for women's and children's health (Setty-Venugopal and Upadhyay 2002). Birth spacing for at least three years can have tremendous health benefits: for children, it lowers risk for fetal death, pre-term birth, low birth weight, small for gestational age, neonatal death, stunting and being underweight; for mothers, it lowers the risk of maternal death, third-trimester bleeding, anemia, premature rupture of membranes, puerperal endometritis and malnutrition (Faramand and Salvador-Davilia 2003). However, there is need of a region-specific understanding and a thorough grasp of the dynamics of fertility. The determinants of changes in the pace of child-bearing and a comprehensive epidemiological understanding of birth spacing are needed to better understand small and short-term changes in reproduction. Literature on a sequential model of fertility provides strong theoretical justification for expecting different effects across parities.

This study utilizes the Cox model analysis approach for understanding birth spacing data in India. Most prior studies have considered a breastfeeding variable in the form of a fixed covariate with a fixed effect, whereas the appropriate form for this covariate is time-varying with time-dependent effects. Furthermore, few studies validate the developed models with their prediction utilities for birth spacing. In this regard, the present study has utilized the Cox model analyses to see the effect of breastfeeding as a time-varying and time-dependent factor on birth spacing in order to provide input to policy planners.

\section{Material and Methods}

Data used in the present study are from the National Family Health Survey (NFHS-I) 1992-93, India (International Institute for Population Sciences [IIPS] 1995). The NFHS in Uttar Pradesh (UP) is a state-representative survey of 11,438 ever-married women of age 13-49 years. The parityspecific hazards models for birth spacing in UP have been worked out utilizing available data on 2,118 women of parity-I, 1,897 women of parity-II, 1,511 women of parity-III, 1,180 women of parity-IV and 918 women of parity-V. These women were non-sterilized and currently married. Results in this study provide information on factors associated with experiencing next live birth, namely the second (first birth spacing), third (second birth spacing), fourth (third birth spacing), fifth (fourth birth spacing) and sixth (fifth birth spacing). For all analysis related to birth spacing, as per the method followed by Trussell et al. (1985), the interval between two live births was divided into five categories: $\leq 15$ months, 16-21 months, 22-27 months, 28-33 month and $\geq 34$ months, for meaningful results.

All the selected probable covariates for analysis to identify important factors related to first to fifth birth spacing in UP were considered in Cox hazards model analysis. This was done because each variable showed at least a moderate association $(p<.25)$ under univariate analyses in at least one birth spacing (Cox 1972; Harrell 2001). Linearity and proportionality assumptions were checked in the model. However, in some cases, more importance was given to theoretical rather than purely statistical considerations. Among all the covariates, breastfeeding did not satisfy the proportionality assumption. To assess the proportionality assumption of period of breastfeeding in the present study, birth spacing was categorized as 0-15 months, 16-21 months, 22-27 months, 28-33 months and $\geq 34$ months, based on exploratory analysis to derive meaningful results. Hence, consideration of breastfeeding in Cox hazards model analysis was taken as a time-varying covariate with a timedependent effect (Trussell et al. 1985).

First-order interaction between covariates was tested using stratified analysis. No interaction was found between the variables; therefore, interaction terms were not considered in data analysis. There was also no evidence of perfect or strong collinearity among the covariates after exploratory correlation analysis (Fox 1997).

Validation to quantify the prediction utility of the models was done through the bootstrapping procedure (Efron 1983 1986; Efron and Gong 1983; Efron and Tibshirani 1993; Linnet 1989). This procedure (with 200 re-samples) is used to estimate the optimism in how well predicted survival 
probability estimates from the developed Cox model track the corresponding Kaplan-Meier survival probability (Kaplan and Meier 1958). This validates the model for calibration accuracy. A shrinkage coefficient (Van Houwelingen and Le Cessie 1990) was also calculated to quantify overfitting of the model. The discrimination aspect of the validation of the model is further measured through Somer's Dxy rank correlation between predicted log hazard and observed survival time (Harrell 2001; Harrell et al. 1996).

In an attempt to demonstrate the predictive utility of the developed models for policy planners, the expected probabilities for a woman not attaining her next live birth with some selected characteristics were worked out. The event of "next live birth" was identified as delivery of a live baby. These probabilities may help in finding that if a change in relation to selected variable(s) is made possible, what additional gain may be expected in comparison to its prevailing average level. This additional gain can easily be obtained by subtracting the probabilities reported against a considered level of a variable or a combination of variables from that reported against the average level of variables present in the model. Obviously, average probability provides the probability of not attaining the next live birth at a prevailing average level of variables present in the final model under a particular period of breastfeeding. Predictive probabilities for a woman not attaining next live birth are calculated as explained by Dickson et al. (1989).

The analyses were performed in various packages, namely SPSS 12.00, BMDP version 7.0 (University of California, 1992) and S-Plus 4.0, 1988-97, (Mathsoft Inc., Seattle, WA 981093044). Predicted probabilities of survival were performed through macros on Microsoft Excel 2000.

\section{Results}

Parity-specific percentages according to different variables regarding who experienced the next live birth are presented in Table 1. As a general trend, the proportion of women experiencing next live birth decreased with an increase in the parity of the woman. A lower proportion of women belonging to the following groups experienced a next live birth: urban background, ever contraceptive use, higher previous birth interval, surviving index child, higher husband's education, semi-pucca and pucca ${ }^{1}$ houses, media exposure, less distance from primary health centres and breastfeeding for more than or equal to 28 months.

Table 1. Parity-specific demographic characteristics of women who experienced next live birth

\begin{tabular}{|l|l|c|c|c|c|c|}
\hline \multirow{2}{*}{ Variables } & \multirow{5}{*}{ Category } & \multicolumn{5}{|c|}{ Parity } \\
\cline { 3 - 7 } & & I & II & III & IV & V \\
\hline Religion/caste & SC/ST Hindu & 42.0 & 36.1 & 40.6 & 44.1 & 33.0 \\
\hline & Other Hindu & 40.0 & 37.0 & 30.1 & 30.2 & 29.2 \\
\hline & Non-Hindu & 49.0 & 37.1 & 41.2 & 32.9 & 32.3 \\
\hline Place of residence & Rural & 42.0 & 39.4 & 33.3 & 34.2 & 31.2 \\
\hline & Urban & 40.6 & 26.1 & 31.3 & 30.2 & 27.6 \\
\hline Women's education & Illiterate & 42.1 & 39.2 & 35.9 & 34.9 & 31.1 \\
\hline & Primary & 44.5 & 42.6 & 28.4 & 24.8 & 32.3 \\
\hline & Middle & 45.0 & 33.1 & 32.3 & 36.7 & 17.7 \\
\hline & 2High school & 34.4 & 18.3 & 16.3 & 24.5 & 29.2 \\
\hline
\end{tabular}




\begin{tabular}{|c|c|c|c|c|c|c|}
\hline Ever contraceptive use & No & 40.6 & 37.1 & 34.9 & 33.9 & 31.8 \\
\hline & Yes & 47.0 & 35.9 & 24.6 & 31.5 & 32.1 \\
\hline \multirow[t]{2}{*}{ Ever fetal loss } & No & 40.9 & 37.2 & 34.0 & 33.7 & 31.9 \\
\hline & Yes & 46.2 & 35.5 & 28.6 & 32.8 & 26.4 \\
\hline \multirow[t]{3}{*}{ Previous birth interval } & $<24$ Months & - & 40.5 & 37.6 & 45.0 & 38.4 \\
\hline & 24-36 Month & - & 40.3 & 36.3 & 34.2 & 31.6 \\
\hline & $>36$ Months & - & 30.1 & 25.9 & 24.6 & 16.0 \\
\hline \multirow[t]{2}{*}{ Sex of index child } & Male & 42.1 & 36.1 & 32.0 & 34.0 & 28.8 \\
\hline & Female & 41.1 & 35.6 & 34.0 & 32.9 & 32.6 \\
\hline \multirow[t]{2}{*}{ Survival status of index child } & Alive & 38.9 & 34.1 & 30.7 & 31.1 & 27.3 \\
\hline & Dead & 59.7 & 64.6 & 59.3 & 54.2 & 54.2 \\
\hline \multirow[t]{2}{*}{ Woman's occupation } & Not employed & 41.6 & 37.0 & 34.0 & 33.1 & 30.7 \\
\hline & Employed & 41.3 & 36.2 & 27.6 & 35.3 & 30.4 \\
\hline \multirow[t]{2}{*}{ Husband's occupation } & Not employed & (36.6 & 26.4 & 34.9 & 22.7 & 35.7 \\
\hline & Employed & 41.9 & 37.3 & 32.9 & 33.7 & 30.5 \\
\hline \multirow[t]{4}{*}{ Husband's education } & Illiterate & 41.0 & 39.4 & 37.7 & 34.6 & 30.2 \\
\hline & Primary & 46.2 & 41.0 & 34.2 & 39.1 & 34.2 \\
\hline & Middle & 40.7 & 39.0 & 34.5 & 33.7 & 31.7 \\
\hline & $\geq$ High School & 40.7 & 32.0 & 26.6 & 27.7 & 27.2 \\
\hline \multirow[t]{2}{*}{ Type of house } & Kuchha & 42.7 & 39.5 & 34.6 & 35.6 & 31.7 \\
\hline & Semipucca+Pucca & 40.4 & 35.1 & 31.0 & 30.8 & 29.2 \\
\hline \multirow[t]{2}{*}{ Media exposure } & No & 42.8 & 40.1 & 35.4 & 35.6 & 32.2 \\
\hline & Yes & 40.0 & 32.0 & 28.6 & 29.1 & 26.1 \\
\hline \multirow{2}{*}{$\begin{array}{l}\text { Distance of primary health } \\
\text { centre }\end{array}$} & $\geq 2 \mathrm{kms}$ & 41.5 & 39.2 & 32.6 & 35.3 & 31.3 \\
\hline & $<2 \mathrm{kms}$ & 41.9 & 30.6 & 34.0 & 28.2 & 28.1 \\
\hline \multirow[t]{5}{*}{ Breastfeeding (months) } & $\geq 1$ & 39.6 & 35.5 & 31.7 & 31.4 & 29.6 \\
\hline & $\geq 16$ & 43.9 & 39.6 & 35.1 & 35.0 & 32.4 \\
\hline & $\geq 22$ & 44.5 & 38.9 & 37.2 & 35.8 & 31.4 \\
\hline & $\geq 28$ & 32.4 & 23.9 & 20.4 & 18.1 & 20.8 \\
\hline & $\geq 34$ & 32.8 & 19.5 & 16.8 & 13.3 & 14.6 \\
\hline Total & & 41.6 & 36.9 & 33.0 & 33.5 & 30.6 \\
\hline
\end{tabular}

$\mathrm{SC} / \mathrm{ST}=$ scheduled caste/scheduled tribe. 
The majority of these women belonged to categories of other Hindu, rural residence, no (ever) contraceptive use, surviving index child and employment of husband. Women at each parity were similar in relation to religion/caste, place of residence, (ever) contraceptive use, previous birth interval, sex of index child, survival status of index child, husband's occupation, type of house, distance of primary health centre and breastfeeding. As parity increased, there was an increase in the proportion of women in the categories of illiteracy, employment status (earning for livelihood), illiteracy of husband, no media exposure and breastfeeding for longer periods. In the same way, for obvious reasons, the average age of women at the time of birth of the index child also revealed an increasing trend with increasing parity.

Univariate analysis of first to fifth birth intervals is presented in Table 2 . These results are in the form of $\exp (\beta)$ along with $95 \%$ confidence interval $(\mathrm{CI})$ where $\exp (\beta)$ means unadjusted rate ratio (RR). As is evident from these results, religion/caste, place of residence, woman's and husband's education, ever contraceptive use, ever fetal loss, sex of index child, woman's and husband's occupation, type of house, distance of primary health centre, media exposure, previous birth interval and breastfeeding played an important part in extending birth space in at least one of the birth intervals (first to fifth).

Table 2. Unadjusted RR and $95 \% \mathrm{Cl}$ of first to fifth birth

\begin{tabular}{|c|c|c|c|c|c|c|}
\hline \multirow[t]{2}{*}{ Variables } & \multirow[t]{2}{*}{ Categories } & Model I & Model II & Model III & Model IV & Model V \\
\hline & & RR \& C.I. 95\% & RR \& C.I. 95\% & RR \& C.I. 95\% & RR \& CI 95\% & RR \& Cl 95\% \\
\hline \multirow{2}{*}{$\begin{array}{l}\text { Religion/ } \\
\text { caste }^{a}\end{array}$} & Non-Hindu & $1.08(0.91-1.28)$ & $0.80(0.66-0.98)$ & $0.75(0.59-0.95)$ & $0.67(0.53-0.85)$ & $0.81(0.61-1.08)$ \\
\hline & Other Hindu & $1.50(1.21-1.85)$ & $1.03(0.80-1.34)$ & $1.03(0.78-1.36)$ & $0.84(0.62-1.14)$ & $0.95(0.66-1.35)$ \\
\hline $\begin{array}{l}\text { Place of } \\
\text { residence }^{b}\end{array}$ & Urban & $1.01(0.85-1.20)$ & $0.54(0.44-0.67)$ & $0.76(0.60-0.97)$ & $0.70(0.54-0.91)$ & $0.75(0.54-1.05)$ \\
\hline \multirow{3}{*}{$\begin{array}{l}\text { Women's } \\
\text { education }\end{array}$} & Primary & $1.13(0.92-1.39)$ & $1.05(0.84-1.32)$ & $0.83(0.62-1.12)$ & $0.60(0.40-0.88)$ & $1.09(0.70-1.70)$ \\
\hline & Middle & $1.10(0.86-1.42)$ & $0.90(0.66-1.23)$ & $0.55(0.36-0.86)$ & $0.82(0.51-1.32)$ & $0.46(0.20-1.04)$ \\
\hline & $\begin{array}{l}\geq \text { High } \\
\text { school }\end{array}$ & $0.88(0.71-1.10)$ & $0.35(0.25-0.48)$ & $0.31(0.19-0.52)$ & $0.54(0.31-0.94)$ & $0.87(0.41-1.84)$ \\
\hline $\begin{array}{l}\text { Ever contra- } \\
\text { ceptive use }^{d}\end{array}$ & Yes & $1.10(0.93-1.31)$ & $0.79(0.65-0.96)$ & $0.61(0.47-0.78)$ & $0.72(0.55-0.94)$ & $0.62(0.45-0.86)$ \\
\hline Ever fetal loss ${ }^{\mathrm{e}}$ & Yes & $0.80(0.66-0.97)$ & $0.80(0.66-0.97)$ & $0.79(0.63-1.00)$ & $0.79(0.63-1.00)$ & $0.67(0.50-0.89)$ \\
\hline \multirow[t]{2}{*}{$\begin{array}{l}\text { Previous birth } \\
\text { interval }^{f}\end{array}$} & $\begin{array}{l}24-36 \\
\text { months }\end{array}$ & - & $0.94(0.78-1.11)$ & $1.05(0.85-1.30)$ & $0.85(0.67-1.07)$ & $0.83(0.63-1.09)$ \\
\hline & $36+$ months & - & $0.75(0.62-0.91)$ & $0.81(0.65-1.03)$ & $0.65(0.50-0.83)$ & $0.57(0.42-0.76)$ \\
\hline $\begin{array}{l}\text { Sex of index } \\
\text { child }^{g}\end{array}$ & Male & $0.86(0.76-0.99)$ & $1.16(1.01-1.35)$ & $1.21(1.01-1.44)$ & $1.10(0.91-1.34)$ & $1.36(1.07-1.71)$ \\
\hline $\begin{array}{l}\text { Survival status } \\
\text { of index child }\end{array}$ & Alive & $0.48(0.40-0.56)$ & $2.39(1.96-2.93)$ & $2.62(2.03-3.38)$ & $2.60(1.98-2.40)$ & $2.69(2.02-3.60)$ \\
\hline $\begin{array}{l}\text { Women's } \\
\text { occupation }\end{array}$ & Employed & $0.85(0.70-1.04)$ & $0.80(0.65-0.99)$ & $0.71(0.55-0.92)$ & $0.87(0.68-1.12)$ & $0.90(0.68-1.19)$ \\
\hline $\begin{array}{l}\text { Husband's } \\
\text { occupation' }\end{array}$ & Employed & $0.93(0.69-1.24)$ & $1.16(0.73-1.83)$ & $0.98(0.59-1.64)$ & $1.08(0.4-2.62)$ & $0.71(0.29-1.73)$ \\
\hline
\end{tabular}




\begin{tabular}{|c|c|c|c|c|c|c|}
\hline \multirow{3}{*}{$\begin{array}{l}\text { Husband's } \\
\text { education }\end{array}$} & Primary & $1.18(0.96-1.45)$ & $1.05(0.85-1.31)$ & $1.02(0.81-1.31)$ & $1.25(0.96-1.62)$ & $1.12(0.83-1.51)$ \\
\hline & Middle & $1.10(0.90-1.35)$ & $1.01(0.81-1.27)$ & $0.96(0.74-1.25)$ & $1.00(0.74-1.35)$ & $1.27(0.88-1.82)$ \\
\hline & $\begin{array}{l}\geq \text { High } \\
\text { school }\end{array}$ & $1.05(0.90-1.24)$ & $0.74(0.61-0.89)$ & $0.72(0.57-0.90)$ & $0.78(0.60-1.01)$ & $0.83(0.60-1.15)$ \\
\hline Type of house' & $\begin{array}{l}\text { Pucca+Semi } \\
\text { Pucca }\end{array}$ & $1.04(0.91-1.18)$ & $0.83(0.71-0.96)$ & $0.82(0.68-0.98)$ & $0.79(0.64-0.96)$ & $0.88(0.69-1.12)$ \\
\hline $\begin{array}{l}\text { Media expo- } \\
\text { sure }^{m}\end{array}$ & Yes & $1.00(0.87-1.14)$ & $0.74(0.63-0.87)$ & $0.67(0.55-0.81)$ & $0.71(0.57-0.89)$ & $0.69(0.53-0.91)$ \\
\hline $\begin{array}{l}\text { Distance } \\
\text { primary health } \\
\text { centren }^{n}\end{array}$ & $<2 \mathrm{~km}$ & $1.02(0.88-1.18)$ & $0.69(0.58-0.83)$ & $0.97(0.79-1.19)$ & $0.68(0.54-0.87)$ & $0.76(0.57-1.02)$ \\
\hline Birth interval & 1-15 month & $0.17(0.12-2.09)$ & $0.16(0.10-0.27)$ & $0.18(0.10-0.33)$ & $0.16(0.08-0.30)$ & $0.13(0.06-0.29)$ \\
\hline Breastfeeding $^{\circ}$ & $\geq 1$ month & $1.42(1.11-1.81)$ & $1.93(1.43-2.59)$ & $1.48(1.00-2.18)$ & $1.36(0.95-1.96)$ & $1.64(1.01-2.66)$ \\
\hline Birth interval & $\begin{array}{l}16-21 \\
\text { month }\end{array}$ & $0.17(0.11-0.25)$ & $0.79(0.47-1.29)$ & $0.26(0.12-0.56)$ & $0.27(0.10-0.73)$ & $0.21(0.07-0.64)$ \\
\hline Breastfeeding $^{\circ}$ & $\geq 16$ month & $0.99(0.80-1.22)$ & $0.77(0.61-0.97)$ & $0.91(0.69-1.21)$ & $0.91(0.66-1.25)$ & $0.95(0.67-1.34)$ \\
\hline Birth interval & $\begin{array}{l}22-27 \\
\text { month }\end{array}$ & $0.18(0.11-0.29)$ & $0.52(0.27-1.02)$ & $0.80(0.29-2.16)$ & $1.59(0.52-4.90)$ & $1.21(0.29-5.09)$ \\
\hline Breastfeeding $^{\circ}$ & $\geq 22$ month & $0.79(0.62-1.01)$ & $0.65(0.50-0.83)$ & $0.66(0.49-0.88)$ & $0.60(0.43-0.85)$ & $0.51(0.35-0.75)$ \\
\hline Birth interval & $\begin{array}{l}\text { 28-33 } \\
\text { month }\end{array}$ & $0.05(0.01-0.22)$ & $0.70(0.32-1.53)$ & $0.40(0.15-1.11)$ & $0.39(0.11-1.36)$ & $1.65(0.58-4.69)$ \\
\hline Breastfeeding $^{\circ}$ & $\geq 28$ month & $0.70(0.48-1.04)$ & $0.62(0.41-0.95)$ & $0.54(0.34-0.87)$ & $0.53(0.32-0.87)$ & $0.61(0.32-1.14)$ \\
\hline Birth interval & $\geq 34$ month & $0.73(0.34-1.54)$ & $1.44(0.57-3.65)$ & $0.82(0.31-2.15)$ & $1.32(0.39-4.45)$ & $10.8(1.30-91.3)$ \\
\hline Breastfeeding $^{\circ}$ & $\geq 34$ month & $0.64(0.32-1.31)$ & $0.28(0.13-0.62)$ & $0.31(0.13-0.75)$ & $0.24(0.08-0.70)$ & $0.04(0.01-0.32)$ \\
\hline
\end{tabular}

$\mathrm{Cl}=$ confidence interval; $\mathrm{RR}=$ relative risk; $\mathrm{SC} / \mathrm{ST}=$ scheduled caste/scheduled tribe

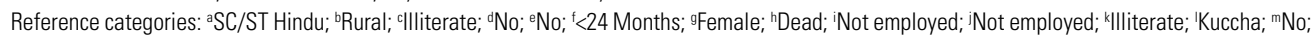
${ }^{\mathrm{n}} \geq 2 \mathrm{~km}$; 'Less than the given.

The multivariate Cox models are presented in Table 3. The subset of variables entered into the parity-specific final model vary from first to fifth birth spacing. Under this procedure, some of the variables partially entered into the model. However, to make a meaningful presentation, partially entered variables are fully considered in presentation of final models. Moreover, irrespective of statistical significance, women's age at index child was forced into the model at step zero for necessary adjustment in relation to age, because age is a well-known confounder of birth spacing. Further, the square of women's age at index child was also considered in the model in view of the non-linear relationship.

The variables in the order they entered into the models for various birth intervals are (i) for first birth spacing: breastfeeding (22-27 months), breastfeeding (28-33 months), breastfeeding (0-15 months), ever fetal loss, religion/caste, education of woman (high school and above) and sex of index child; (ii) for second birth spacing: breastfeeding (22-27 months), education of woman (high school and above), breastfeeding ( $\geq 34$ months), breastfeeding ( $0-15$ months), breastfeeding (16-21 months), survival status of index child, breastfeeding (28-33 months), place of residence, occupation of woman, education of husband (primary), ever fetal loss; (iii) for third birth spacing: breastfeeding (28-33 months), education of woman (high school and above), breastfeeding (22-27 months), breastfeeding ( $\geq 34$ months), education of woman (middle), ever fetal loss, occupation of 
woman, ever contraceptive use, breastfeeding ( $0-15$ months), survival status of index child, distance from primary health centre, media exposure to women ${ }^{2}$; (iv) for fourth birth spacing: breastfeeding (28-33 months), breastfeeding (22-27 months), place of residence, breastfeeding ( $\geq 34$ months), education of husband (primary), contraceptive use, ever fetal loss, breastfeeding (0-15 months), occupation of woman; and (v) for fifth birth spacing: breastfeeding (22-27 months), breastfeeding ( $\geq 34$ months), education of husband (high school and above), media exposure, ever fetal loss, breastfeeding (0-15 months), place of residence, breastfeeding (28-33 months), education of woman (primary) and education of husband (middle).

Table 3. Multivariate extended Cox hazards models for first to fifth birth intervals

\begin{tabular}{|c|c|c|c|c|c|c|}
\hline \multirow[t]{2}{*}{ Variable } & \multirow[t]{2}{*}{ Categories } & Model I & Model II & Model III & Model IV & ModeI V \\
\hline & & RR \& 95\% CI & RR \& 95\% CI & RR \& 95\% CI & RR \& 95\% Cl & RR \& 95\% Cl \\
\hline $\begin{array}{l}\text { Women's age } \\
\text { at index child }\end{array}$ & Continuous & $1.34(1.07-1.68)$ & $1.26(0.87-1.46)$ & $1.11(0.87-1.42)$ & $1.05(0.84-1.31)$ & 1.09 (0.79-1.50) \\
\hline $\begin{array}{l}\text { Women's age } \\
\text { at index child }\end{array}$ & Continuous & $0.99(0.98-1.00)$ & $0.99(0.99-1.00)$ & $0.99(0.99-1.00)$ & $0.99(0.99-1.00)$ & $0.99(0.99-1.00)$ \\
\hline $\begin{array}{l}\text { Place of resi- } \\
\text { dence }^{a}\end{array}$ & Urban & - & $0.69(0.54-0.88)$ & & $0.53(0.39-0.71)$ & $0.73(0.52-1.02)$ \\
\hline \multirow{2}{*}{$\begin{array}{l}\text { Religion/ } \\
\text { caste }^{\mathrm{b}}\end{array}$} & Other Hindu & $1.11(0.93-1.33)$ & - & - & & \\
\hline & Non-Hindu & $1.33(1.06-1.66)$ & - & - & & \\
\hline \multirow{3}{*}{$\begin{array}{l}\text { Women's } \\
\text { education }\end{array}$} & Primary & $0.93(0.75-1.15)$ & $1.01(0.80-1.29)$ & $0.98(0.72-1.33)$ & & $1.50(0.92-2.42)$ \\
\hline & Middle & $0.86(0.66-1.11)$ & $0.79(0.57-1.10)$ & $0.57(0.36-0.91)$ & & $0.68(0.29-1.60)$ \\
\hline & $\begin{array}{l}\geq \text { High } \\
\text { school }\end{array}$ & $0.73(0.57-0.93)$ & $0.35(0.24-0.52)$ & $0.26(0.15-0.46)$ & & $0.95(0.41-2.18)$ \\
\hline \multirow{3}{*}{$\begin{array}{l}\text { Husband's } \\
\text { education d }\end{array}$} & Primary & - & $1.30(1.04-1.61)$ & & $1.38(1.06-1.79)$ & 1.21 (0.89-1.64) \\
\hline & Middle & - & $0.99(0.79-1.25)$ & & $1.13(0.83-1.52)$ & $1.49(1.02-2.17)$ \\
\hline & $\begin{array}{l}\geq \text { High } \\
\text { school }\end{array}$ & - & $0.77(0.63-0.94)$ & & $0.95(0.72-1.24)$ & $0.77(0.53-1.12)$ \\
\hline $\begin{array}{l}\text { Ever contra- } \\
\text { ceptive use }^{\mathrm{e}}\end{array}$ & yes & - & - & $0.73(0.55-0.96)$ & $0.74(0.56-0.97)$ & \\
\hline $\begin{array}{l}\text { Ever fetal } \\
\text { loss }^{f}\end{array}$ & Yes & $0.74(0.61-0.90)$ & $0.77(0.63-0.94)$ & $0.69(0.54-0.88)$ & $0.76(0.60-0.97)$ & $0.72(0.53-0.97)$ \\
\hline $\begin{array}{l}\text { Sex of index } \\
\text { child }^{g}\end{array}$ & Male & $0.88(0.77-1.01)$ & - & - & & \\
\hline $\begin{array}{l}\text { Survival } \\
\text { status of } \\
\text { index child }\end{array}$ & Alive & - & $0.73(0.58-0.92)$ & $0.72(0.52-0.99)$ & & \\
\hline $\begin{array}{l}\text { Occupation of } \\
\text { women }^{i}\end{array}$ & Employed & - & $0.74(0.60-0.92)$ & $0.75(0.58-0.98)$ & $0.78(0.61-1.01)$ & \\
\hline $\begin{array}{l}\text { Media expo- } \\
\text { sure }^{\mathrm{j}}\end{array}$ & Yes & - & - & $0.83(0.67-1.02)$ & & $0.68(0.50-0.91)$ \\
\hline
\end{tabular}




\begin{tabular}{|l|l|l|l|l|l|l|}
\hline $\begin{array}{l}\text { Distance } \\
\text { of primary } \\
\text { health centre }\end{array}$ & $<2 \mathrm{~km}$ & - & - & $1.22(0.98-1.52)$ & & \\
\hline Birth interval & $0-15$ month & $0.18(0.12-0.27)$ & $0.16(0.10-0.27)$ & $0.18(0.10-0.34)$ & $0.16(0.09-0.31)$ & $0.13(0.06-0.30)$ \\
\hline Breastfeeding & $\geq 1$ month & $1.46(1.15-1.87)$ & $2.46(1.80-3.36)$ & $1.93(1.25-2.99)$ & $1.49(1.0-2.15)$ & $1.67(1.02-2.73)$ \\
\hline Birth interval & $\begin{array}{l}16-21 \\
\text { month }\end{array}$ & $0.18(0.12-0.27)$ & $0.82(0.50-1.37)$ & $0.29(0.14-0.63)$ & $0.28(0.10-0.77)$ & $0.20(0.07-0.63)$ \\
\hline Breastfeeding & $\geq 16$ month & $0.90(0.73-1.11)$ & $0.68(0.54-0.87)$ & $0.79(0.60-1.05)$ & $0.82(0.59-1.14)$ & $0.93(0.65-1.32)$ \\
\hline Birth interval & $\begin{array}{l}22-27 \\
\text { month }\end{array}$ & $0.19(0.12-0.30)$ & $0.57(0.29-1.11)$ & $0.82(0.30-2.22)$ & $1.69(0.55-5.22)$ & $1.29(0.31-5.40)$ \\
\hline Breastfeeding & $\geq 22$ month & $0.77(0.60-0.98)$ & $0.59(0.46-0.76)$ & $0.63(0.47-0.85)$ & $0.57(0.41-0.81)$ & $0.54(0.37-0.80)$ \\
\hline Birth interval & $\begin{array}{l}28-33 \\
\text { month }\end{array}$ & $0.05(0.01-0.23)$ & $0.69(0.31-1.51)$ & $0.40(0.15-1.10)$ & $0.38(0.11-1.35)$ & $1.70(0.60-4.84)$ \\
\hline Breastfeeding & $\geq 28$ month & $0.69(0.47-1.02)$ & $0.67(0.44-1.02)$ & $0.57(0.35-0.92)$ & $0.52(0.32-0.86)$ & $0.51(0.27-0.96)$ \\
\hline Birth interval & $\geq 34$ month & $0.65(0.31-1.38)$ & $1.28(0.50-3.23)$ & $1.09(0.41-2.88)$ & $1.11(0.33-3.76)$ & $9.95(1.18-83.68)$ \\
\hline Breastfeeding & $\geq 34$ month & $0.72(0.35-1.45)$ & $0.29(0.13-0.63)$ & $0.33(0.14-0.80)$ & $0.25(0.08-0.75)$ & $0.05(0.01-0.37)$ \\
\hline
\end{tabular}

$\mathrm{Cl}=$ confidence interval; $\mathrm{RR}=$ relative risk.

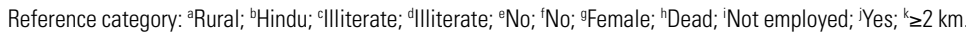
${ }^{*}$ Significant at $<.05$.

A comparison of variables entered in the final multivariate extended Cox models related to various birth spacing reveals that after breastfeeding, ever experience of fetal loss emerged as an important covariate in extending each of the examined birth intervals. Education of woman (specifically high school and above) was revealed as a significant protective factor between first to third birth spacing. This variable was not significant under the fifth birth spacing, and it did not enter in the model for the fourth birth spacing at all. Employment status of woman was also a significant protective factor under second and third birth intervals. Education of husband (at the middle and primary level) was also significantly associated with second, fourth and fifth birth intervals, quite often as a risk factor. It is obviously a contrary result. Media exposure was a significant protective factor for the fifth birth spacing. While survival status of index child emerged as a significant protective factor for birth intervals two and three, ever contraceptive use emerged as a protective factor for intervals three and four. Place of residence also entered into the model but did not reveal any specific pattern in relation to various birth intervals. In summary, variables varied from the first to the fifth birth intervals.

\section{Validation}

Calibration curves dealing with the bootstrap estimate of calibration accuracy for 30 months for first to fourth birth intervals and calibration accuracy for 24 months for the fifth birth interval from the final extended Cox models are presented in Figures 1-5. Bias-corrected calibration seemed satisfactory in each case, with a few exceptions. These exceptions were noticed for three groups under the first, second and fifth intervals, five groups under the third, and four groups under fourth interval. However, their not having next childbirth probabilities were slightly better than predicted. Further, these errors fall in a low range in absolute terms. Table 4 clearly shows that shrinkage coefficients related to first to fifth birth intervals are $0.97,0.96,0.78,0.93$ and 0.93 , respectively. This clearly indicates that with regard to calibration accuracy, $3 \%, 4 \%, 22 \%, 7 \%$ and $7 \%$ of the model fitting will be noisy in relation to those with first, second, third, fourth and fifth birth intervals, respectively. Thus, the shrinkage coefficient could easily be used to shrink predictions to yield better calibration 
in the case of the third birth spacing. However, the calculated Somer's Dxy rank correlation related to models for various birth spacing are $-0.40,-0.61,-0.68,-0.65$ and -0.69 respectively. As the honest estimate of the discrimination aspect of predictive accuracy, this measure also indicates satisfactory validity of the developed models, including that for third birth spacing. In summary, the measures of validity of developed models demonstrate that these models are good enough to describe the parity-specific birth spacing in UP.

Figures 1-5. Calibration curves

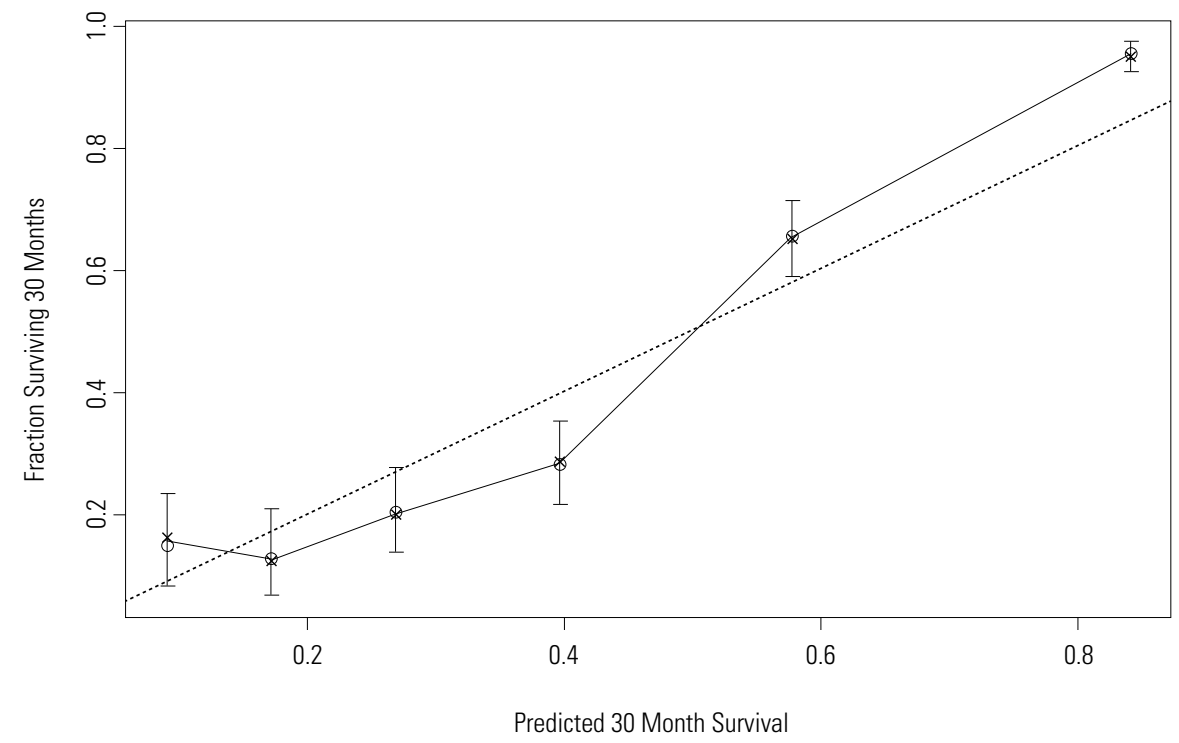

Bootstrap estimates of calibration accuracy for 30 months estimates for the final extended Cox model for 1 st birth spacing. Dots correspond to apparent predictive accuracy. X marks the bootstrap-corrected estimates.

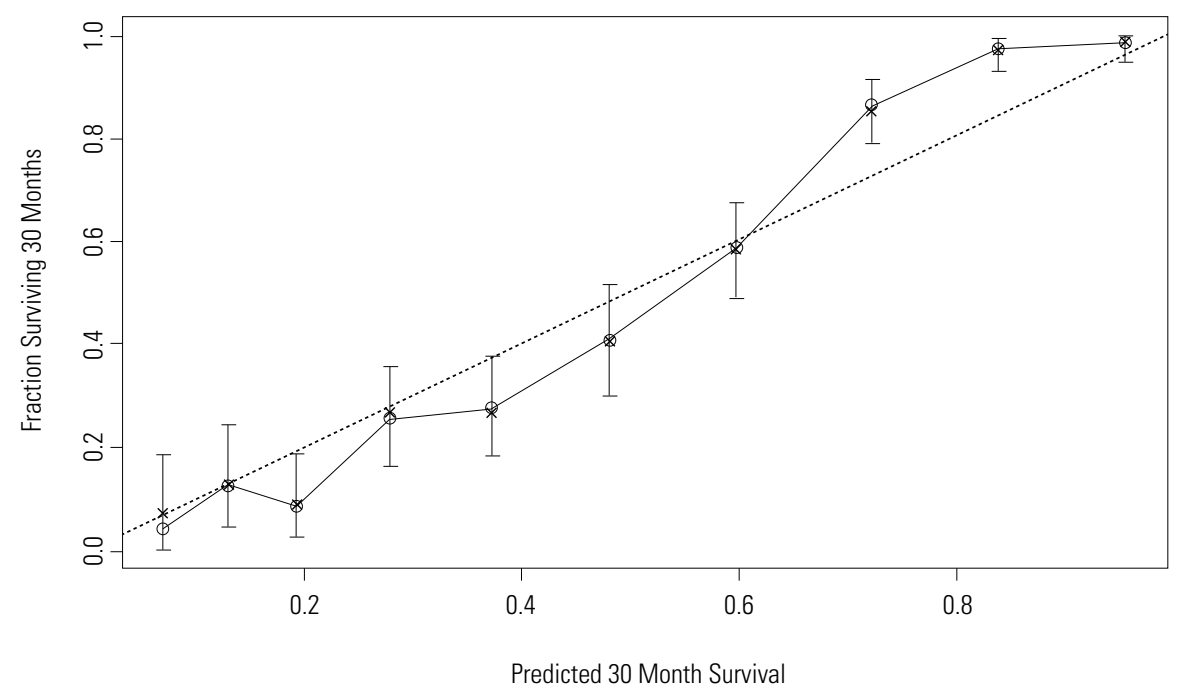

Bootstrap estimates of calibration accuracy for 30 months estimates from the final extended Cox model for 2 nd birth spacing. Dots correspond to apparent predictive accuracy. X marks the bootstrap-corrected estimates. 


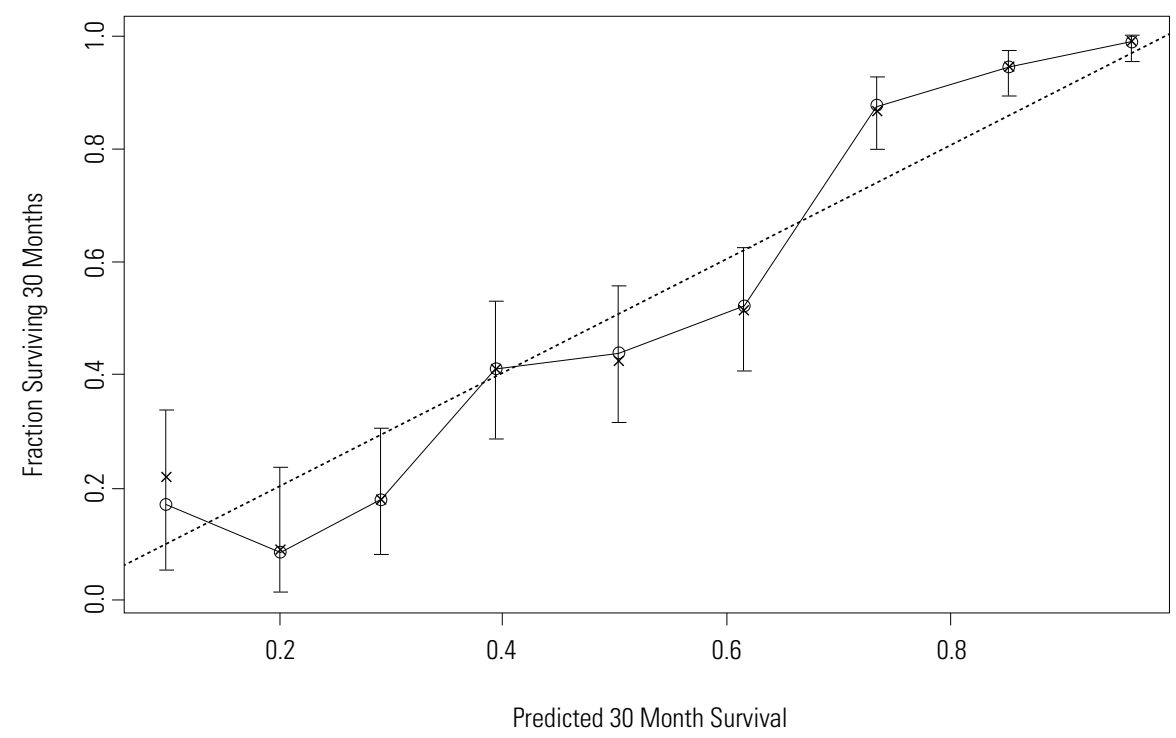

Bootstrap estimates of calibration accuracy for 30 months estimates from the final extended Cox model for 3 rd birth spacing. Dots correspond to apparent predictive accuracy. X marks the bootstrap-corrected estimates.

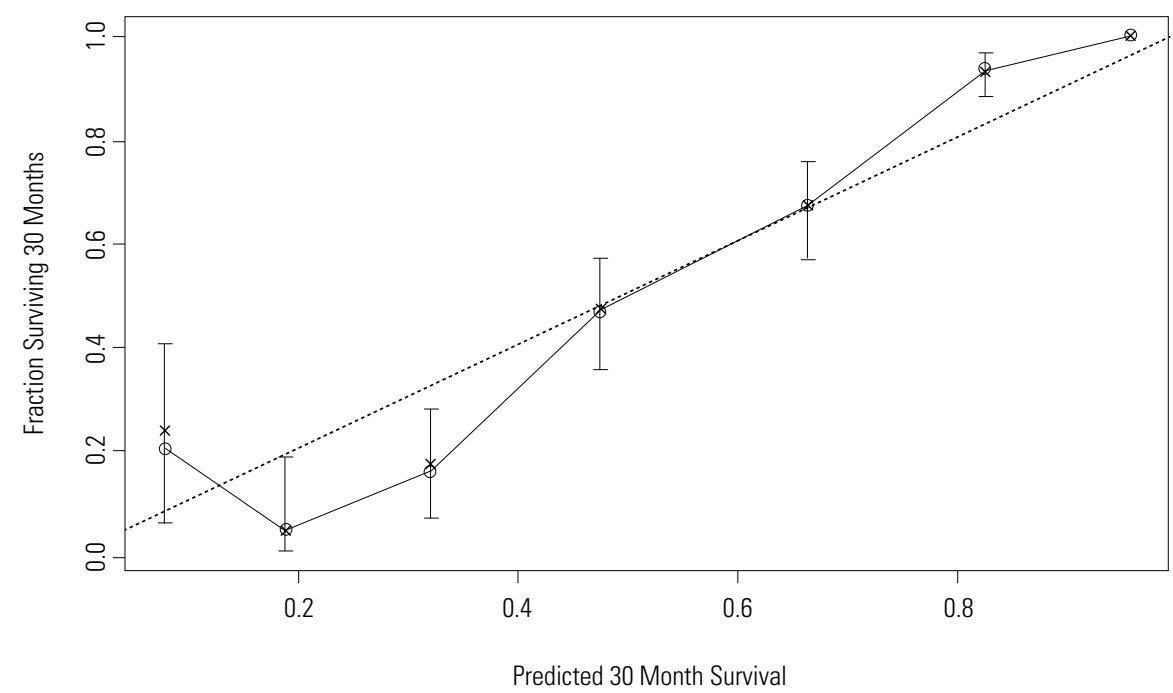

Bootstrap estimates of calibration accuracy for 30 months estimates from the final extended Cox model for 4 th birth spacing. Dots correspond to apparent predictive accuracy. X marks the bootstrap-corrected estimates. 


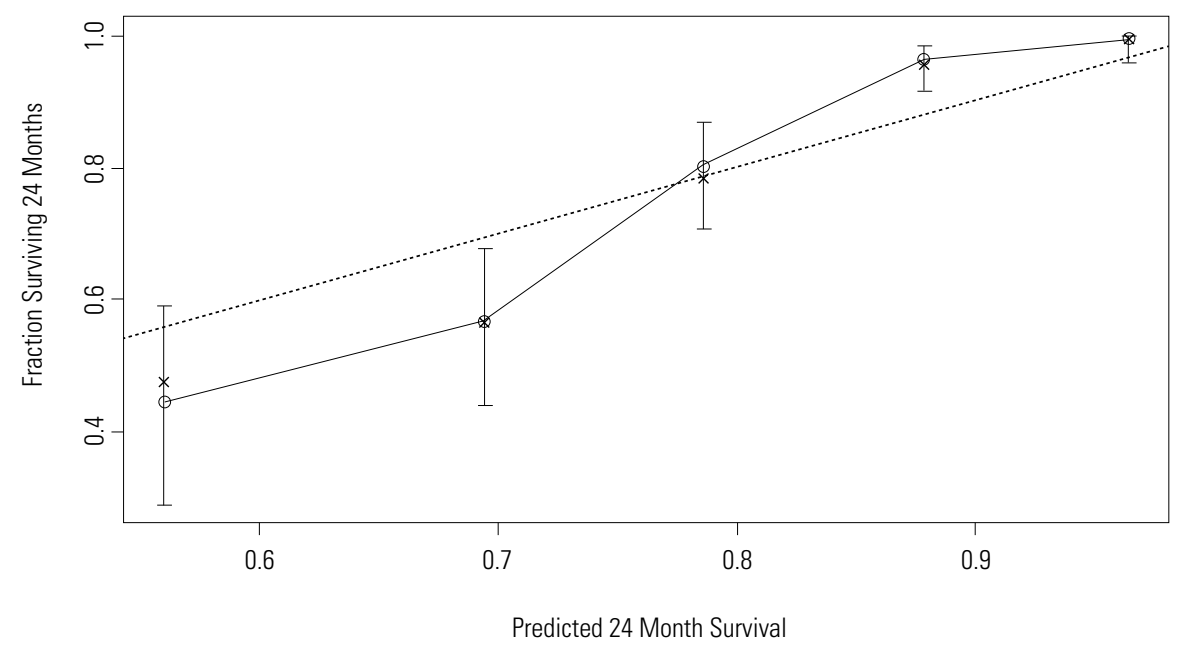

Bootstrap estimates of calibration accuracy for 24 months estimates from the final extended Cox model for 5 th birth spacing. Dots correspond to apparent predictive accuracy. $\mathrm{X}$ marks the bootstrap-corrected estimates.

\section{Predictions}

Predictions based on final models for first to fifth birth intervals are listed in Tables 5.1 to 5.5, respectively, in relation to some selected individual as well as group of variables, which may be modified through some interventions.

As evident from Table 5.1, survival probability (i.e., not having a second live birth after the first) related to first birth spacing decreased over a period of time (i.e., from 12 to 48 months). However, it increased with an increased period of breastfeeding up to the category of 28-33 months. In contrast, the survival probability within the category of 34 and above months was smaller than even the category $0-15$ months. Within each category, there was an increasing trend in the probability of not having the next live birth in relation to an increase in the education of women. But the maximum benefit is noticed once the woman's education is high school (and above). These results clearly indicate that if women are educated at the high school (and above) level and they breastfeed their children, maximum benefit with regard to extension of birth spacing can be derived, specifically up to the period of 27 months after the birth. Similar results are evident for second and third birth intervals (Tables 5.2 and 5.3). Woman's education did not enter in the model for fourth birth spacing (Table 5.4). Hence, the prediction analysis under the fourth birth spacing in this relation is not possible. No specific trend could be noticed for the fifth birth spacing (Table 5.5). It is interesting to note that these probabilities increased up to the third birth spacing with an increase in parity of women. However, this observation may be attributed to some extent to change in variables in the final model. As evident from Tables 5.2 and 5.3, high school (and above) education of women may contribute more than even the survival of the index child. The importance of high school (and above) education for women is also visible in comparison to the employment status of women (Tables 5.2 and 5.3). Also, women's education is found to be more important than that of the husband (Table 5.2). 
Table 4. Validity indices of extended Cox hazards models developed for parity-specific birth spacing (first to fifth)

\begin{tabular}{|c|c|c|c|c|c|c|}
\hline & $\begin{array}{l}\text { Index } \\
\text { original }\end{array}$ & Training & Test & Optimism & $\begin{array}{l}\text { Index } \\
\text { corrected }\end{array}$ & Re-Sample \\
\hline \multicolumn{7}{|l|}{ Parity-I } \\
\hline Shrinkage & 1.00 & 1.00 & 0.97 & 0.03 & 0.97 & 200 \\
\hline \multicolumn{7}{|l|}{ Coefficient } \\
\hline$D_{x y}$ & -0.41 & -0.42 & -0.41 & -0.01 & -0.40 & 200 \\
\hline \multicolumn{7}{|l|}{ Parity-II } \\
\hline Shrinkage & 1.00 & 1.00 & 0.96 & 0.04 & 0.96 & 200 \\
\hline \multicolumn{7}{|l|}{ Coefficient } \\
\hline$D_{x y}$ & -0.61 & -0.62 & -0.61 & -0.01 & -0.61 & 200 \\
\hline \multicolumn{7}{|l|}{ Parity-III } \\
\hline Shrinkage & 1.00 & 1.00 & 0.78 & 0.22 & 0.78 & 200 \\
\hline \multicolumn{7}{|l|}{ Coefficient } \\
\hline$D_{x y}$ & -0.72 & -0.74 & -0.70 & -0.04 & -0.68 & 200 \\
\hline \multicolumn{7}{|l|}{ Parity-IV } \\
\hline Shrinkage & 1.00 & 1.00 & 0.93 & 0.07 & 0.93 & 200 \\
\hline \multicolumn{7}{|l|}{ Coefficient } \\
\hline $\mathrm{D}_{x y}$ & -0.66 & -0.66 & -0.64 & -0.01 & -0.65 & 200 \\
\hline \multicolumn{7}{|l|}{ Parity-V } \\
\hline Shrinkage & 1.00 & 1.00 & 0.93 & 0.07 & 0.93 & 200 \\
\hline \multicolumn{7}{|l|}{ Coefficient } \\
\hline$D_{x y}$ & -0.70 & -0.70 & -0.69 & -0.01 & -0.69 & 200 \\
\hline
\end{tabular}

$D_{x y}:$ Somer's D-rank correlation.

Table 5.2 provides the opportunity to compare the relative role of survival of the index child and high school (and above) education of the husband. It is clearly demonstrated that each of these variables contributed equally if they were considered individually. This is also true in the case of consideration with the high school (and above) education of women in the model. A similar comparison between media exposure and survival of the index child is shown in Table 5.3. This reveals that media exposure may contribute slightly more to extended birth spacing than the survival of index child in the case of individual consideration. Once they are considered individually along with high school (and above) education of women, an additional slight gain is observed for these two variables, but it is of the same magnitude in both cases. In the same way, comparison between high school (and above) education of the husband and media exposure (Table 5.5) reveals that each makes an almost equal contribution individually. This is also true in cases where these variables are considered along with high school (and above) education of women. 
Table 5.1. Estimated probabilities of not having second live birth at specific months after first live birth, by selected characteristics, according to model (first birth spacing)

\begin{tabular}{|c|c|c|c|c|c|c|c|}
\hline \multirow[t]{2}{*}{ Characteristics } & \multicolumn{7}{|c|}{ Probability of not having births at months } \\
\hline & 12 & 18 & 24 & 30 & 36 & 42 & 48 \\
\hline \multicolumn{8}{|l|}{ BREASTFEEDING (0-15 MONTHS) } \\
\hline Average & 0.98 & 0.91 & 0.80 & 0.68 & 0.58 & 0.44 & 0.36 \\
\hline Primary educated women & 0.98 & 0.91 & 0.80 & 0.69 & 0.58 & 0.44 & 0.36 \\
\hline Middle educated women & 0.98 & 0.92 & 0.82 & 0.71 & 0.61 & 0.47 & 0.39 \\
\hline High school and above educated women & 0.98 & 0.93 & 0.84 & 0.75 & 0.66 & 0.53 & 0.45 \\
\hline \multicolumn{8}{|l|}{ BREASTFEEDING (16-21 MONTHS) } \\
\hline Average & 0.99 & 0.95 & 0.88 & 0.80 & 0.72 & 0.61 & 0.55 \\
\hline Primary educated women & 0.99 & 0.94 & 0.87 & 0.79 & 0.72 & 0.61 & 0.53 \\
\hline Middle educated women & 0.99 & 0.95 & 0.88 & 0.81 & 0.74 & 0.63 & 0.56 \\
\hline High school and above educated women & 0.99 & 0.96 & 0.90 & 0.84 & 0.77 & 0.68 & 0.61 \\
\hline \multicolumn{8}{|l|}{ BREASTFEEDING (22-27 MONTHS) } \\
\hline Average & 0.99 & 0.95 & 0.88 & 0.81 & 0.73 & 0.62 & 0.56 \\
\hline Primary educated women & 0.99 & 0.95 & 0.88 & 0.81 & 0.74 & 0.63 & 0.56 \\
\hline Middle educated women & 0.99 & 0.95 & 0.89 & 0.82 & 0.75 & 0.65 & 0.59 \\
\hline High school \& above educated women & 0.99 & 0.96 & 0.91 & 0.85 & 0.79 & 0.70 & 0.64 \\
\hline \multicolumn{8}{|l|}{ BREASTFEEDING (28-33 MONTHS) } \\
\hline Average & 1.00 & 0.99 & 0.97 & 0.95 & 0.92 & 0.89 & 0.86 \\
\hline Primary educated women & 1.00 & 0.99 & 0.97 & 0.95 & 0.93 & 0.89 & 0.86 \\
\hline Middle educated women & 1.00 & 0.99 & 0.97 & 0.95 & 0.93 & 0.90 & 0.87 \\
\hline High school and above educated women & 1.00 & 0.99 & 0.98 & 0.96 & 0.94 & 0.91 & 0.89 \\
\hline \multicolumn{8}{|l|}{ BREASTFEEDING ( $\geq 34$ MONTHS) } \\
\hline Average & 0.96 & 0.85 & 0.67 & 0.51 & 0.38 & 0.23 & 0.16 \\
\hline Primary educated women & 0.96 & 0.85 & 0.68 & 0.51 & 0.38 & 0.23 & 0.17 \\
\hline Middle educated women & 0.96 & 0.86 & 0.70 & 0.54 & 0.41 & 0.26 & 0.19 \\
\hline High school and above educated women & 0.97 & 0.88 & 0.74 & 0.60 & 0.47 & 0.32 & 0.25 \\
\hline
\end{tabular}


Table 5.2. Estimated probabilities of not having third live birth at specific months after second live birth, by selected characteristics, according to model (second birth spacing).

\begin{tabular}{|c|c|c|c|c|c|c|c|}
\hline \multirow[t]{2}{*}{ Characteristics } & \multicolumn{7}{|c|}{ Probability of not having births at months } \\
\hline & 12 & 18 & 24 & 30 & 36 & 42 & 48 \\
\hline \multicolumn{8}{|l|}{ BREASTFEEDING (0-15 MONTHS) } \\
\hline Average & 0.98 & 0.95 & 0.88 & 0.78 & 0.67 & 0.55 & 0.48 \\
\hline Primary educated women & 0.99 & 0.96 & 0.89 & 0.81 & 0.71 & 0.60 & 0.53 \\
\hline Middle educated women & 0.99 & 0.95 & 0.89 & 0.80 & 0.70 & 0.59 & 0.51 \\
\hline High school and above educated women & 0.99 & 0.98 & 0.95 & 0.91 & 0.85 & 0.79 & 0.74 \\
\hline Survival of index child & 0.99 & 0.95 & 0.88 & 0.78 & 0.67 & 0.56 & 0.48 \\
\hline Employed women & 0.99 & 0.95 & 0.89 & 0.79 & 0.74 & 0.62 & 0.52 \\
\hline High school and above educated husband & 0.99 & 0.95 & 0.89 & 0.79 & 0.69 & 0.58 & 0.50 \\
\hline $\begin{array}{l}\text { High school and above educated women + } \\
\text { Survival of index child }\end{array}$ & 0.99 & 0.98 & 0.95 & 0.91 & 0.86 & 0.80 & 0.75 \\
\hline $\begin{array}{l}\text { High school and above educated women + } \\
\text { High school and above educated husband }\end{array}$ & 0.99 & 0.98 & 0.95 & 0.91 & 0.86 & 0.80 & 0.76 \\
\hline \multicolumn{8}{|l|}{ BREASTFEEDING (16-21 MONTHS) } \\
\hline Average & 0.98 & 0.93 & 0.83 & 0.70 & 0.57 & 0.44 & 0.35 \\
\hline Primary educated women & 0.98 & 0.94 & 0.85 & 0.74 & 0.62 & 0.49 & 0.41 \\
\hline Middle educated women & 0.98 & 0.93 & 0.85 & 0.73 & 0.60 & 0.47 & 0.39 \\
\hline High school and above educated women & 0.99 & 0.97 & 0.93 & 0.87 & 0.80 & 0.72 & 0.66 \\
\hline Survival of index child & 0.98 & 0.93 & 0.83 & 0.71 & 0.57 & 0.44 & 0.36 \\
\hline Employed women & 0.98 & 0.93 & 0.84 & 0.73 & 0.60 & 0.48 & 0.40 \\
\hline High school and above educated husband & 0.98 & 0.93 & 0.83 & 0.71 & 0.58 & 0.45 & 0.37 \\
\hline $\begin{array}{l}\text { High school and above educated women + } \\
\text { Survival of index child }\end{array}$ & 0.99 & 0.97 & 0.93 & 0.87 & 0.80 & 0.72 & 0.67 \\
\hline $\begin{array}{l}\text { High school and above educated women + } \\
\text { High school and above educated husband }\end{array}$ & 0.99 & 0.97 & 0.97 & 0.88 & 0.81 & 0.74 & 0.68 \\
\hline \multicolumn{8}{|l|}{ BREASTFEEDING (22-27 MONTHS) } \\
\hline Average & 0.99 & 0.96 & 0.90 & 0.81 & 0.71 & 0.62 & 0.54 \\
\hline Primary educated women & 0.99 & 0.96 & 0.91 & 0.84 & 0.75 & 0.65 & 0.59 \\
\hline Middle educated women & 0.99 & 0.96 & 0.91 & 0.83 & 0.74 & 0.64 & 0.57 \\
\hline High school and above women & 0.99 & 0.98 & 0.96 & 0.92 & 0.87 & 0.82 & 0.78 \\
\hline Survival of index child & 0.99 & 0.96 & 0.90 & 0.81 & 0.72 & 0.62 & 0.54 \\
\hline Employed women & 0.99 & 0.96 & 0.90 & 0.82 & 0.73 & 0.65 & 0.57 \\
\hline High school and above educated husband & 0.99 & 0.96 & 0.90 & 0.82 & 0.73 & 0.63 & 0.56 \\
\hline
\end{tabular}


Table 5.2. Continued

\begin{tabular}{|c|c|c|c|c|c|c|c|}
\hline $\begin{array}{l}\text { High school and above educated women + } \\
\text { Survival of index child }\end{array}$ & 1.00 & 0.98 & 0.96 & 0.92 & 0.88 & 0.83 & 0.79 \\
\hline $\begin{array}{l}\text { High school and above educated women + } \\
\text { High school and above educated husband }\end{array}$ & 1.00 & 0.98 & 0.96 & 0.93 & 0.88 & 0.83 & 0.79 \\
\hline \multicolumn{8}{|l|}{ BREASTFEEDING (28-33 MONTHS) } \\
\hline Average & 0.98 & 0.94 & 0.86 & 0.75 & 0.63 & 0.51 & 0.43 \\
\hline Primary educated women & 0.99 & 0.95 & 0.88 & 0.78 & 0.67 & 0.56 & 0.48 \\
\hline Middle educated women & 0.98 & 0.95 & 0.87 & 0.77 & 0.66 & 0.54 & 0.47 \\
\hline High school and above educated women & 0.99 & 0.98 & 0.94 & 0.89 & 0.83 & 0.76 & 0.71 \\
\hline Survival of index child & 0.98 & 0.94 & 0.86 & 0.75 & 0.63 & 0.51 & 0.43 \\
\hline Employed women & 0.98 & 0.94 & 0.87 & 0.77 & 0.66 & 0.55 & 0.47 \\
\hline High school and above educated husband & 0.98 & 0.95 & 0.87 & 0.77 & 0.65 & 0.53 & 0.46 \\
\hline $\begin{array}{l}\text { High school and above educated women + } \\
\text { Survival of index child }\end{array}$ & 0.99 & 0.98 & 0.94 & 0.90 & 0.84 & 0.77 & 0.72 \\
\hline $\begin{array}{l}\text { High school and above educated women + } \\
\text { High school and above educated husband }\end{array}$ & 0.99 & 0.98 & 0.95 & 0.90 & 0.84 & 0.78 & 0.73 \\
\hline \multicolumn{8}{|l|}{ BREASTFEEDING ( $\geq 34$ MONTHS) } \\
\hline Average & 0.99 & 0.95 & 0.89 & 0.80 & 0.69 & 0.58 & 0.51 \\
\hline Primary educated women & 0.99 & 0.95 & 0.88 & 0.78 & 0.67 & 0.56 & 0.48 \\
\hline Middle educated women & 0.99 & 0.96 & 0.90 & 0.81 & 0.72 & 0.62 & 0.54 \\
\hline High school and above educated women & 0.99 & 0.98 & 0.95 & 0.91 & 0.86 & 0.81 & 0.76 \\
\hline Survival of index child & 0.99 & 0.95 & 0.89 & 0.80 & 0.70 & 0.59 & 0.52 \\
\hline Employed women & 0.99 & 0.96 & 0.91 & 0.84 & 0.75 & 0.66 & 0.59 \\
\hline High school and above educated husband & 0.99 & 0.96 & 0.89 & 0.81 & 0.71 & 0.61 & 0.53 \\
\hline $\begin{array}{l}\text { High school and above educated women + } \\
\text { Survival of index child }\end{array}$ & 0.99 & 0.98 & 0.95 & 0.92 & 0.87 & 0.81 & 0.77 \\
\hline $\begin{array}{l}\text { High school and above educated women + } \\
\text { High school and above educated husband }\end{array}$ & 0.99 & 0.98 & 0.96 & 0.92 & 0.87 & 0.82 & 0.78 \\
\hline
\end{tabular}


Table 5.3. Estimated probabilities of not having fourth live birth at specific months after third live birth, by selected characteristics, according to model (third birth spacing)

\begin{tabular}{|c|c|c|c|c|c|c|c|}
\hline \multirow[t]{2}{*}{ Characteristics } & \multicolumn{7}{|c|}{ Probability of not having births at months } \\
\hline & 12 & 18 & 24 & 30 & 36 & 42 & 48 \\
\hline \multicolumn{8}{|l|}{ BREASTFEEDING (0-15 MONTHS) } \\
\hline Average & 0.98 & 0.94 & 0.88 & 0.79 & 0.68 & 0.59 & 0.51 \\
\hline Primary educated women & 0.98 & 0.93 & 0.86 & 0.78 & 0.65 & 0.56 & 0.47 \\
\hline Middle educated women & 0.99 & 0.96 & 0.92 & 0.86 & 0.78 & 0.71 & 0.65 \\
\hline High school and above educated women & 0.99 & 0.98 & 0.96 & 0.93 & 0.90 & 0.85 & 0.82 \\
\hline Contraceptive use & 0.99 & 0.95 & 0.90 & 0.84 & 0.74 & 0.66 & 0.59 \\
\hline Survival of index child & 0.99 & 0.94 & 0.88 & 0.80 & 0.68 & 0.59 & 0.51 \\
\hline Employed women & 0.99 & 0.95 & 0.90 & 0.83 & 0.73 & 0.66 & 0.58 \\
\hline Media exposure & 0.98 & 0.95 & 0.89 & 0.82 & 0.71 & 0.62 & 0.55 \\
\hline $\begin{array}{l}\text { High school and above educated women+ } \\
\text { Survival of index child }\end{array}$ & 0.99 & 0.98 & 0.96 & 0.94 & 0.89 & 0.86 & 0.82 \\
\hline $\begin{array}{l}\text { High school and above educated women+ } \\
\text { Media exposure }\end{array}$ & 1.00 & 0.98 & 0.97 & 0.94 & 0.90 & 0.87 & 0.84 \\
\hline \multicolumn{8}{|l|}{ BREASTFEEDING (16-21 MONTHS) } \\
\hline Average & 0.99 & 0.95 & 0.92 & 0.86 & 0.77 & 0.70 & 0.64 \\
\hline Primary educated women & 0.99 & 0.96 & 0.91 & 0.85 & 0.75 & 0.68 & 0.61 \\
\hline Middle educated women & 1.00 & 0.97 & 0.95 & 0.91 & 0.85 & 0.80 & 0.75 \\
\hline High school and above women & 1.00 & 0.99 & 0.97 & 0.96 & 0.93 & 0.90 & 0.88 \\
\hline Contraceptive use & 0.99 & 0.97 & 0.93 & 0.89 & 0.82 & 0.76 & 0.71 \\
\hline Survival of index child & 0.99 & 0.96 & 0.92 & 0.86 & 0.78 & 0.71 & 0.64 \\
\hline Employed women & 0.99 & 0.98 & 0.93 & 0.89 & 0.81 & 0.76 & 0.70 \\
\hline Media exposure & 0.99 & 0.96 & 0.92 & 0.87 & 0.79 & 0.73 & 0.67 \\
\hline $\begin{array}{l}\text { High school and above educated women+ } \\
\text { Survival of index child }\end{array}$ & 1.00 & 0.99 & 0.97 & 0.96 & 0.93 & 0.90 & 0.88 \\
\hline $\begin{array}{l}\text { High school and above educated women+ } \\
\text { Media exposure }\end{array}$ & 1.00 & 0.99 & 0.98 & 0.96 & 0.93 & 0.91 & 0.89 \\
\hline \multicolumn{8}{|l|}{ BREASTFEEDING (22-27 MONTHS) } \\
\hline Average & 0.97 & 0.91 & 0.82 & 0.71 & 0.56 & 0.45 & 0.36 \\
\hline Primary educated women & 0.97 & 0.90 & 0.80 & 0.69 & 0.53 & 0.42 & 0.33 \\
\hline Middle educated women & 0.98 & 0.94 & 0.88 & 0.80 & 0.69 & 0.60 & 0.52 \\
\hline High school and above educated women & 0.99 & 0.97 & 0.94 & 0.90 & 0.84 & 0.79 & 0.74 \\
\hline Contraceptive use & 0.98 & 0.93 & 0.86 & 0.77 & 0.64 & 0.54 & 0.46 \\
\hline
\end{tabular}


Table 5.3. Continued

\begin{tabular}{|c|c|c|c|c|c|c|c|}
\hline Survival of index child & 0.97 & 0.91 & 0.82 & 0.72 & 0.57 & 0.46 & 0.37 \\
\hline Employed women & 0.98 & 0.93 & 0.86 & 0.76 & 0.63 & 0.54 & 0.45 \\
\hline Media exposure & 0.98 & 0.92 & 0.84 & 0.74 & 0.60 & 0.50 & 0.41 \\
\hline $\begin{array}{l}\text { High school and above educated women+ } \\
\text { Survival of index child }\end{array}$ & 0.99 & 0.97 & 0.94 & 0.91 & 0.85 & 0.80 & 0.75 \\
\hline $\begin{array}{l}\text { High school and above educated women+ } \\
\text { Media exposure }\end{array}$ & 0.99 & 0.98 & 0.95 & 0.91 & 0.86 & 0.81 & 0.77 \\
\hline \multicolumn{8}{|l|}{ BREASTFEEDING (28-33 MONTHS) } \\
\hline Average & 0.99 & 0.96 & 0.92 & 0.86 & 0.77 & 0.70 & 0.64 \\
\hline Primary educated women & 0.99 & 0.96 & 0.91 & 0.85 & 0.75 & 0.68 & 0.61 \\
\hline Middle educated women & 0.99 & 0.97 & 0.95 & 0.91 & 0.85 & 0.80 & 0.75 \\
\hline High school and above women & 1.00 & 0.99 & 0.97 & 0.97 & 0.93 & 0.90 & 0.88 \\
\hline Contraceptive use & 0.99 & 0.97 & 0.93 & 0.89 & 0.82 & 0.76 & 0.71 \\
\hline Survival of index child & 0.99 & 0.96 & 0.92 & 0.86 & 0.78 & 0.71 & 0.65 \\
\hline Employed women & 0.99 & 0.97 & 0.93 & 0.89 & 0.82 & 0.76 & 0.70 \\
\hline Media exposure & 0.99 & 0.96 & 0.93 & 0.87 & 0.80 & 0.73 & 0.67 \\
\hline $\begin{array}{l}\text { High school and above educated women+ } \\
\text { Survival of index child }\end{array}$ & 1.00 & 0.99 & 0.98 & 0.96 & 0.93 & 0.90 & 0.88 \\
\hline $\begin{array}{l}\text { High school and above educated women+ } \\
\text { Media exposure }\end{array}$ & 1.00 & 0.99 & 0.98 & 0.96 & 0.94 & 0.91 & 0.89 \\
\hline \multicolumn{8}{|l|}{ BREASTFEEDING ( $\geq 34$ MONTHS) } \\
\hline Average & 0.98 & 0.94 & 0.87 & 0.79 & 0.66 & 0.57 & 0.50 \\
\hline Primary educated women & 0.98 & 0.93 & 0.86 & 0.77 & 0.64 & 0.54 & 0.46 \\
\hline Middle educated women & 0.99 & 0.96 & 0.91 & 0.86 & 0.77 & 0.70 & 0.63 \\
\hline High school and above women & 0.99 & 0.98 & 0.96 & 0.93 & 0.89 & 0.85 & 0.81 \\
\hline Contraceptive use & 0.99 & 0.95 & 0.90 & 0.83 & 0.73 & 0.65 & 0.58 \\
\hline Survival of index child & 0.98 & 0.94 & 0.87 & 0.79 & 0.67 & 0.58 & 0.50 \\
\hline Employed women & 0.99 & 0.95 & 0.90 & 0.83 & 0.73 & 0.64 & 0.57 \\
\hline Media exposure & 0.98 & 0.94 & 0.88 & 0.81 & 0.70 & 0.61 & 0.53 \\
\hline $\begin{array}{l}\text { High school and above educated women+ } \\
\text { Survival of index child }\end{array}$ & 0.99 & 0.98 & 0.96 & 0.93 & 0.89 & 0.85 & 0.81 \\
\hline $\begin{array}{l}\text { High school and above educated women+ } \\
\text { Media exposure }\end{array}$ & 1.00 & 0.98 & 0.96 & 0.94 & 0.90 & 0.86 & 0.83 \\
\hline
\end{tabular}


Table 5.4. Estimated probabilities of not having fifth live birth at specific months after fourth live birth, by selected characteristics, according to model (fourth birth spacing).

\begin{tabular}{|c|c|c|c|c|c|c|c|}
\hline \multirow[t]{2}{*}{ Characteristics } & \multicolumn{7}{|c|}{ Probability of not having births at months } \\
\hline & 12 & 18 & 24 & 30 & 36 & 42 & 48 \\
\hline \multicolumn{8}{|l|}{ BREASTFEEDING (0-15 MONTHS) } \\
\hline Average & 0.99 & 0.95 & 0.88 & 0.80 & 0.70 & 0.58 & 0.52 \\
\hline Contraceptive use & 0.99 & 0.96 & 0.91 & 0.84 & 0.76 & 0.66 & 0.60 \\
\hline Employed women & 0.99 & 0.96 & 0.90 & 0.84 & 0.74 & 0.64 & 0.59 \\
\hline High school and above & 0.99 & 0.95 & 0.89 & 0.82 & 0.73 & 0.62 & 0.56 \\
\hline Educated husband + employed women & 1.00 & 0.98 & 0.95 & 0.92 & 0.87 & 0.82 & 0.78 \\
\hline \multicolumn{8}{|l|}{ BREASTFEEDING (16-21 MONTHS) } \\
\hline Average & 0.99 & 0.95 & 0.89 & 0.81 & 0.71 & 0.60 & 0.54 \\
\hline Contraceptive use & 0.99 & 0.96 & 0.91 & 0.85 & 0.77 & 0.67 & 0.62 \\
\hline Employed women & 0.99 & 0.96 & 0.91 & 0.84 & 0.76 & 0.66 & 0.60 \\
\hline High school and above & 0.99 & 0.86 & 0.90 & 0.83 & 0.74 & 0.64 & 0.58 \\
\hline Educated husband + employed women & 1.00 & 0.98 & 0.96 & 0.92 & 0.88 & 0.85 & 0.79 \\
\hline \multicolumn{8}{|l|}{ BREASTFEEDING (22-27 MONTHS) } \\
\hline Average & 0.96 & 0.81 & 0.60 & 0.42 & 0.24 & 0.12 & 0.08 \\
\hline Contraceptive use & 0.97 & 0.85 & 0.68 & 0.51 & 0.33 & 0.19 & 0.13 \\
\hline Employed women & 0.96 & 0.84 & 0.66 & 0.49 & 0.31 & 0.17 & 0.22 \\
\hline High school and above & 0.96 & 0.83 & 0.64 & 0.46 & 0.28 & 0.15 & 0.10 \\
\hline Educated husband + employed women & 0.98 & 0.92 & 0.83 & 0.72 & 0.45 & 0,45 & 0.38 \\
\hline \multicolumn{8}{|l|}{ BREASTFEEDING (28-33 MONTHS) } \\
\hline Average & 0.99 & 0.96 & 0.90 & 0.83 & 0.74 & 0.64 & 0.59 \\
\hline Contraceptive use & 0.99 & 0.97 & 0.92 & 0.87 & 0.79 & 0.71 & 0.66 \\
\hline Employed women & 0.99 & 0.96 & 0.92 & 0.86 & 0.78 & 0.70 & 0.65 \\
\hline High school and above & 0.99 & 0.96 & 0.91 & 0.85 & 0.77 & 0.68 & 0.62 \\
\hline Educated husband + employed women & 1.00 & 0.98 & 0.96 & 0.93 & 0.85 & 0.85 & 0.82 \\
\hline \multicolumn{8}{|l|}{ BREASTFEEDING ( $\geq 34$ MONTHS) } \\
\hline Average & 0.99 & 0.94 & 0.86 & 0.78 & 0.66 & 0.54 & 0.48 \\
\hline Contraceptive use & 0.99 & 0.95 & 0.89 & 0.82 & 0.73 & 0.62 & 0.56 \\
\hline Employed women & 0.99 & 0.95 & 0.89 & 0.81 & 0.71 & 0.60 & 0.54 \\
\hline High school and above & 0.99 & 0.95 & 0.88 & 0.80 & 0.69 & 0.58 & 0.52 \\
\hline Educated husband + employed women & 1.00 & 0.98 & 0.95 & 0.91 & 0.79 & 0.79 & 0.76 \\
\hline
\end{tabular}


Table 5.5. Estimated probabilities of not having sixth live birth at specific months after fifth live birth, by selected characteristics, according to model (fifth birth spacing)

\begin{tabular}{|c|c|c|c|c|c|c|c|}
\hline \multirow[t]{2}{*}{ Characteristics } & \multicolumn{7}{|c|}{ Probability of not having births at months } \\
\hline & 12 & 18 & 24 & 30 & 36 & 42 & 48 \\
\hline \multicolumn{8}{|l|}{ BREASTFEEDING (0-15 MONTHS) } \\
\hline Average & 0.99 & 0.96 & 0.91 & 0.85 & 0.77 & 0.68 & 0.65 \\
\hline Primary educated women & 0.99 & 0.94 & 0.88 & 0.79 & 0.67 & 0.57 & 0.53 \\
\hline Middle educated women & 0.99 & 0.97 & 0.94 & 0.90 & 0.84 & 0.78 & 0.75 \\
\hline High school and above educated women & 0.99 & 0.96 & 0.92 & 0.86 & 0.78 & 0.70 & 0.67 \\
\hline Media exposure & 0.99 & 0.97 & 0.94 & 0.89 & 0.82 & 0.75 & 0.72 \\
\hline High school and above educated husband & 0.99 & 0.97 & 0.94 & 0.89 & 0.82 & 0.75 & 0.72 \\
\hline $\begin{array}{l}\text { High school and above educated women+ } \\
\text { High school and above educated husband }\end{array}$ & 0.99 & 0.97 & 0.94 & 0.90 & 0.83 & 0.77 & 0.74 \\
\hline $\begin{array}{l}\text { High school and above educated women+ } \\
\text { Media exposure }\end{array}$ & 0.99 & 0.97 & 0.94 & 0.89 & 0.83 & 0.76 & 0.73 \\
\hline \multicolumn{8}{|l|}{ BREASTFEEDING (16-21 MONTHS) } \\
\hline \multicolumn{8}{|l|}{ Average } \\
\hline Primary educated women & 0.99 & 0.95 & 0.90 & 0.82 & 0.71 & 0.62 & 0.58 \\
\hline Middle educated women & 0.99 & 0.98 & 0.95 & 0.91 & 0.86 & 0.80 & 0.78 \\
\hline High school and above educated women & 0.99 & 0.97 & 0.93 & 0.88 & 0.81 & 0.74 & 0.71 \\
\hline Media exposure & 0.99 & 0.98 & 0.95 & 0.90 & 0.84 & 0.78 & 0.75 \\
\hline High school and above educated husband & 0.99 & 0.98 & 0.95 & 0.90 & 0.84 & 0.79 & 0.76 \\
\hline $\begin{array}{l}\text { High school and above educated women+ } \\
\text { High school and above educated husband }\end{array}$ & 0.99 & 0.98 & 0.95 & 0.91 & 0.85 & 0.80 & 0.77 \\
\hline $\begin{array}{l}\text { High school and above educated women+ } \\
\text { Media exposure }\end{array}$ & 0.99 & 0.98 & 0.95 & 0.91 & 0.85 & 0.79 & 0.77 \\
\hline \multicolumn{8}{|l|}{ BREASTFEEDING (22-27 MONTHS) } \\
\hline Average & 0.97 & 0.89 & 0.76 & 0.61 & 0.43 & 0.31 & 0.26 \\
\hline Primary educated women & 0.96 & 0.84 & 0.67 & 0.48 & 0.29 & 0.17 & 0.14 \\
\hline Middle educated women & 0.98 & 0.92 & 0.84 & 0.72 & 0.57 & 0.45 & 0.40 \\
\hline High school and above educated women & 0.97 & 0.89 & 0.78 & 0.63 & 0.46 & 0.33 & 0.28 \\
\hline Media exposure & 0.98 & 0.91 & 0.82 & 0.69 & 0.53 & 0.41 & 0.36 \\
\hline High school and above educated husband & 0.98 & 0.94 & 0.87 & 0.77 & 0.64 & 0.54 & 0.49 \\
\hline $\begin{array}{l}\text { High school and above educated women+ } \\
\text { High school and above educated husband }\end{array}$ & 0.98 & 0.92 & 0.83 & 0.71 & 0.56 & 0.44 & 0.39 \\
\hline $\begin{array}{l}\text { High school and above educated women+ } \\
\text { Media exposure }\end{array}$ & 0.98 & 0.92 & 0.83 & 0.70 & 0.55 & 0.43 & 0.38 \\
\hline
\end{tabular}




\begin{tabular}{|c|c|c|c|c|c|c|c|}
\hline \multicolumn{8}{|l|}{ BREASTFEEDING (28-33 MONTHS) } \\
\hline Average & 0.96 & 0.86 & 0.72 & 0.54 & 0.35 & 0.23 & 0.19 \\
\hline Primary educated women & 0.95 & 0.80 & 0.61 & 0.40 & 0.22 & 0.11 & 0.08 \\
\hline Middle educated women & 0.98 & 0.91 & 0.80 & 0.66 & 0.50 & 0.37 & 0.32 \\
\hline High school and above educated women & 0.97 & 0.87 & 0.73 & 0.56 & 0.38 & 0.25 & 0.21 \\
\hline Media exposure & 0.97 & 0.89 & 0.78 & 0.63 & 0.46 & 0.33 & 0.28 \\
\hline High school and above educated husband & 0.97 & 0.90 & 0.78 & 0.63 & 0.46 & 0.34 & 0.29 \\
\hline $\begin{array}{l}\text { High school and above educated women+ } \\
\text { High school and above educated husband }\end{array}$ & 0.98 & 0.90 & 0.79 & 0.65 & 0.49 & 0.36 & 0.31 \\
\hline $\begin{array}{l}\text { High school and above educated women+ } \\
\text { Media exposure }\end{array}$ & 0.97 & 0.90 & 0.79 & 0.65 & 0.50 & 0.35 & 0.30 \\
\hline \multicolumn{8}{|l|}{ BREASTFEEDING ( $\geq 34$ MONTHS) } \\
\hline Average & 0.98 & 0.92 & 0.83 & 0.71 & 0.56 & 0.44 & 0.39 \\
\hline Primary educated women & 0.97 & 0.88 & 0.76 & 0.60 & 0.43 & 0.30 & 0.25 \\
\hline Middle educated women & 0.99 & 0.99 & 0.88 & 0.80 & 0.68 & 0.58 & 0.53 \\
\hline High school and above educated women & 0.98 & 0.93 & 0.84 & 0.73 & 0.58 & 0.46 & 0.41 \\
\hline Media exposure & 0.98 & 0.94 & 0.87 & 0.77 & 0.65 & 0.54 & 0.49 \\
\hline High school and above educated husband & 0.99 & 0.94 & 0.87 & 0.78 & 0.65 & 0.54 & 0.50 \\
\hline $\begin{array}{l}\text { High school and above educated women+ } \\
\text { High school and above educated husband }\end{array}$ & 0.99 & 0.94 & 0.88 & 0.79 & 0.67 & 0.57 & 0.52 \\
\hline $\begin{array}{l}\text { High school and above educated women+ } \\
\text { Media exposure }\end{array}$ & 0.99 & 0.94 & 0.88 & 0.78 & 0.66 & 0.56 & 0.51 \\
\hline
\end{tabular}

\section{Discussion}

On account of indices reported regarding validity of each developed model (calibration curve, shrinkage coefficient, and Somer's Dxy rank correlation), it is clear that each of the parity-specific hazards models that were developed describe the respective birth spacing. To our knowledge, there is no study on birth spacing in which an exercise related to the validity of the developed Cox hazards models has been carried out. Therefore, there is no scope to compare the developed models in the present study with those reported under other studies.

Age and parity have long been regarded as factors that influence lactational infertility and breastfeeding behaviour, since the period of lactational amenorrhea tends to be longer for older and multiparous than for younger and primiparous women (Saadeh and Benbouzid 1990). Further, the World Health Organization (WHO) recommends an interval of at least 24 months to reduce the risk of adverse maternal, perinatal and neonatal outcomes (WHO 2006). Some studies have also suggested adverse outcomes in birth intervals of more than 59 months (Conde-Agudelo and Belizàn 2000). Thus, age was forced into the model; however, it did not emerge a significant factor.

Breastfeeding was the only covariate found to be a significant protective factor associated with each birth spacing. When analyzing the data on birth spacing in the Philippines, Malaysia and Indonesia, Trussell et al. (1985) also considered breastfeeding as a time-varying covariate with timedependent effect. They did not carry out a parity-specific analysis, but they included parity as one of the covariates in data analyses. Results obtained in relation to breastfeeding in UP did not coincide 
with the findings of the Trussell et al. (1985) study. Also, observations made in UP, especially in relation to third and higher birth orders, were supported by the observations made by Trussell et al. (1985) in Indonesia. Anderson and Bean (1985) considered breastfeeding in the form of any breastfeeding as well as exclusive breastfeeding at the beginning of birth spacing, and reported breastfeeding as a significant protective factor related to the most recent birth spacing. Considering breastfeeding as a time-varying covariate with a fixed effect, they observed that breastfeeding was a significant protective factor in addition to other covariates considered in their data analysis.

The education of women emerged as another important variable that protected against birth spacing in the present study, especially for first to third and fifth birth intervals. Women's education was consistently related to the likelihood of another birth at each birth spacing, with high school (and above) educated women experiencing a significantly lower probability of a subsequent birth. This finding is supported by results of other studies (Gandotra et al. 1998; Ojha 1998; Rahman and Davanzo 1993; Rajaram 1994; Swenson and Thang 1993; Teachman and Heckert 1985) and suggests that women's education is a prime determinant of fertility and that increasing the educational attainment of women is one of the most beneficial measures to reduce fertility. In contrast, Rodriguez et al. (1983) discovered that education of women had relatively little effect on birth spacing except at the higher parities. Surprisingly, more recent analyses of birth spacing carried out by Ojha (1998) and Richter et al. (1994) did not reveal a significant association between the education of women and birth spacing.

Religion/caste was significantly associated with only the first birth spacing. Ojha (1998) considered this variable in the form of non-Hindu and Hindu religion and concluded that non-Hindu women had a higher risk of having the next live birth in comparison to Hindu women in relation to first to fifth birth intervals in UP. In the present study, this variable was included jointly with caste, and Hindu religion was further subdivided in a Scheduled Caste/Scheduled Tribe category. This may account for the difference in results obtained under the present analysis.

This study showed that place of residence was significantly associated with second, fourth and fifth birth intervals. Swenson and Thang (1993) also suggested that urban-rural differences persisted at most birth orders, and urban-rural differentials are the primary source of variations in fertility between different areas of a country. Similar findings were reported by Trussell et al. (1985).

Occupation of women has been assessed as a risk/protective factor in relation to birth spacing in a few studies. This study has clearly indicated that working status of women, not occupation, was a significant protective factor specifically for second and third birth intervals. Trussell et al. (1985) assessed the role of employment status of women (away from home) and found no significant impact on birth spacing, whereas Richter et al. (1994) assessed the impact of occupation of women, considering various categories. Interestingly, they noticed that women employed as salesgirls and manufacturing workers, and those who were self-employed, were significantly less likely to go for the next birth.

Various studies (Blanchard and Bogaert 1997; Bogaert 2000; Greenberg and White 1967; Wyshak 1969) have reported that birth intervals are comparatively longer following the birth of a male in comparison to a female child. However, sex of index child did not emerge as a significant associated factor in each of three country data analyses, namely Philippines, Malaysia and Indonesia (Trussell et al. 1985). But Swenson and Thang (1993) reported male index child as a protective factor for birth spacing of women's first and second parities. The present study also indicated the likelihood of male index child being a protective factor only for first birth spacing in UP. In contrast, Ojha (1998) reported that sex of the index child played a significant role in first to fifth birth intervals.

Survival of index child emerged as a significant protective factor for second and third birth spacing. The role of survival of index child for birth spacing has also been documented by many other studies (Marino-Navarro 1987; Oheneba-Sakyi and Heaton 1993; Ojha 1998; Palloni and Rafalimanana 1999; Rahman and Davanzo 1993; Rajaram et al. 1994; Suchindran and Adlakha, 1984).

Many studies have reported on the significant role of contraceptive use in extending birth spacing (Moreno-Navarro 1987; Rajaram et al. 1994; Islam and Mahmud 1995). However, data on parity- 
specific contraceptive use were not available for the present study. On account of its theoretical importance, as reported in earlier studies, information on (ever) contraceptive use was considered in the analysis for each birth spacing. This was done in view of the possibility that couples who have used modern contraceptives once might use them again when they feel the need. Contraceptive use was a significant protective factor for higher-order birth spacing.

Similarly, media exposure had a protective impact on higher-order birth spacing. The latter finding was supported by Gandotra (1998). This is similar to Gebreselassie et al. (2008) who, in a multivariate analysis of data from four countries, found that exposure to mass media had a significant positive association with adoption of contraceptive methods.

Ever fetal loss extended birth spacing significantly. Chapple (2009) found that birth spacing interval corresponding to the lowest odds of an adverse outcome varied, based on timing of previous fetal death. While early fetal death was associated with a low risk of perinatal outcome for any interval longer than six months, no interval was associated with a late fetal death. Also, no interval was identified as the appropriate interval that offered protection against adverse maternal outcomes. In our study, we did not have access to fetal loss at each birth interval and therefore cannot extend the analysis to say how much it affected birth spacing.

Education of husband was a significant factor. This is supported by a study in Mozambique by RamaRao et al. (2006). De la Paz (2010) also found that husband's education had an effect at each birth spacing.

Studies (Davanzo and Starbird 1991; Miller et al. 1992; Rodriguez et al. 1983; Swenson and Thang 1993; Trussell et al. 1985) have documented the importance of previous birth interval in extending succeeding birth spacing. The results of the present study did not support the existing literature with regard to this finding.

\section{Conclusion}

Socio-economic factors are potential confounders of birth spacing and adverse maternal outcomes. This study utilizes information from NFHS 92-93 data to see the effects of socio-economic factors on breastfeeding and its impact on birth spacing. Breastfeeding has been known to affect lactational amenorrhea, leading to an increase in birth spacing. This study is a first in terms of developing models that optimize the NFHS-I data to validate and predict. In summary, in terms of policy implications, this study has revealed the importance of a region-specific epidemiological understanding of public health issues such as birth spacing. Within a region, sub-grouping according to parity/ birth order of birth spacing data may be helpful in planning and in showing more specific strategies. Further, the study has clearly emphasized the need for education programs, including not only formal education of woman/mother or husband/father, but also effective messages (media exposure) regarding the importance of issues like contraceptive use and breastfeeding, especially in UP.

\section{Limitations}

A major limitation of the present study lies in the type of data collected on maternity history of women in NFHS-I. The age of the data is also a limitation, although the findings are still relevant to the present, since no such study has been conducted previously. The data on some important covariates like income, post-partum amenorrhea and behavioural aspects were not available. Further, data on modern contraceptive use and fetal loss at each birth interval were also not available. In absence of these data, under strong assumptions, ever contraceptive use and ever experience of fetal loss were considered in the analyses.

\section{Notes}

${ }^{1}$ Pucca House: A pucca house is one, which has walls and roof made of the following material: burnt bricks, stones (packed with lime or cement), cement concrete, timber, ekra, tiles, GCI (Galvanised Corrugated Iron) sheets, asbestos cement sheet, RBC,(Reinforced Brick Concrete), RCC ( Reinforced Cement Concrete) and timber etc.

Kutcha House: The walls and/or roof of this type of house are made of material other than those mentioned above, such as un-burnt bricks, bamboos, mud, grass, reeds, thatch, loosely packed stones, etc. 
Semi -Pucca house: A house that has fixed walls made up of pucca material but roof is made up of the material other than those used for pucca house.

Reference: Government of India. 2005. Instructions to Enumerators /Supervisors for Conduct of Fifth Economic Census. Author. Retrieved March 24, 2012. <www.mospi.gov.in/ecs_Ins_Manual_part_I_two.htm>.

${ }^{2}$ This part of the data was previously published: Dwivedi, S.N. and R. Singh. 2003. "On Assessing the Child Spacing Effect of Breastfeeding Using Cox Proportional Hazards Model with NFHS data." Demography India 32(2): 215-24. It is here quoted and included for purposes of comparison and further analysis, validation and prediction.

\section{References}

Anderson, D.L. and L.L Bean. 1985. "Birth Spacing and Fertility Limitation: A Behavioral Analysis of Nineteenth Century Population.” Demography 22(2): 169-83.

Blanchard, R. and A.F. Bogaert. 1997. "Additive Effects of Older Brothers and Homosexual Brothers in the Prediction of Marriage and Cohabitation." Behavior Genetics 27: 45-54.

Bogaert, A.F. 2000. "Birth Order and Sexual Orientation in a National Probability Sample." Journal of Sex Research 37(4): 361-8.

Chapple, T. 2009. Effects of Interpregnancy Intervals Immediately Following a Fetal Death on Maternal and Perinatal Health (Doctoral Dissertation). Retrieved from ProQuest Dissertations and Theses Database. (AAT 3381155)

Conde-Agudelo, A. and J.M. Belizàn. 2000. "Maternal Morbidity and Mortality Associated with Interpregnancy Interval: Cross Sectional Study.” British Medical Journal 321(7271): 1255-9.

Cox, D.R. 1972. "Regression Models and Life Tables (with Discussion)." Journal of the Royal Statistical Society Series B 34(2): 187-220.

Davanzo, J. and E. Starbird. 1991. "Correlates of Short Interbirth Intervals in Peninsular Malaysia: Their Pathways of Influence through Breastfeeding and Contraceptive Use." Studies in Family Planning 22(4): 241-54.

de la Paz, L. 2010. An Analysis of the Timing of Fertility in Rural India. Department of Economics, Stanford University, Stanford, CA. Retreived March 12, 2011. <http://economics.stanford.edu/files/De\%20la\%20Paz HThesis2010.pdf>.

Dickson, E.R., P.M. Grambsch, T.R. Fleming, L.D. Fisher and A. Langworthy. 1989. "Prognosis in Primary Biliary Cirrohsis: Model for Decision Making." Hepatology 10(1): 1-7.

Efron, B. 1983. "Estimating the Error Rate of a Prediction Rule: Improvement on Cross-validation.” Journal of the American Statistical Association 78(382): 316-31.

Efron, B. 1986. "How Biased Is the Apparent Error Rate of a Prediction Rule?" Journal of the American Statistical Association 81(394): 461-70.

Efron, B. and G. Gong. 1983. "A Leisurely Look at the Bootstrap, the Jackknife, and Cross-validation." American Statistician 37(1): 36-48.

Efron, B. and R. Tibshirani. 1993. An Introduction to the Bootstrap. New York: Chapman and Hall.

Faramand, T.H. and G. Salvador-Davilia. 2003. Optimal Birth Spacing Saves Lives and Improves Health and Nutrition. Optimal Birth Spacing - An Activity of the CATALYST Consortium. Retrieved February 21, 2012. $<\mathrm{http}$ ///www.coregroup.org/storage/documents/Workingpapers/smrh_OBSI_Overview.pdf>.

Fox, J. 1997. Applied Regression Analysis, Linear Models, and Related Methods. Thousand Oaks, CA: Sage Publications.

Gandotra, M.M., R.D. Retherford, A. Pandey, N.Y. Luther and V.K. Mishra. 1998. Fertility in International for Population Sciences (IIPS). National Family Health Survey Subject Reports. Uttar Pradesh, India, 1992-1993. Bombay: IIPS.

Gebreselassie, T., S.O. Rutstein and V. Mishra. 2008. Contraceptive Use, Breastfeeding, Amenorrhea and Abstinence during the Postpartum Period: An Analysis of Four Countries. DHS Analytical Studies 14. Calverton, Maryland, USA: Macro International.

Greenberg, R.A. and C. White. 1967. "The Sexes of Consecutive Sibs in Human Sibships.” Human Biology 39(4): 374-404.

Harrell, F.E. 2001. Regression Modeling Strategies with Application to Linear Models, Logistic Regression, and Survival Analysis. New York: Springer-Verlag.

Harrell, F.E., K.L. Lee and D.B. Mark. 1996. “Tutorial in Biostatistics Multivariable Prognostic Models: Issues 
in Developing Models, Evaluating Assumptions and Adequacy, and Measuring and Reducing Errors." Statistics in Medicine 15(4): 361-87.

International Institute for Population Sciences (IIPS) and East-West Center. 1998. India: National Family Health Survey. Bulletin No. 9. IIPS and Honolulu: East-West Center.

International Institute for Population Sciences (IIPS). 1995. India: National Family Health Survey (NFHS-I) 1992-93. Mumbai: IIPS.

Islam, M.M. and M. Mahmud. 1995. "Contraception among Adolescents in Bangladesh.” Asia-Pacific Population Journal, 10(1): 21-38.

Kaplan, E. and P. Meier. 1958. "Non-parametric Estimation from Incomplete Observations." Journal of the American Statistical Association 53(282): 457-81.

Linnet, K. 1989. “Assessing Diagnostic Tests by a Strictly Proper Scoring Rule.” Statistics in Medicine 8(5): 608-18.

Miller, J.E., J. Trussell, A.R. Pabley and B. Vaughan, B. 1992. "Birth Spacing and Child Mortality in Bangladesh and the Philippines." Demography 29(2): 305-16.

Moreno-Navarro, L. 1987. "Fertility Change in Five Latin American Countries: A Covariance Analysis of Birth Intervals.” Demography 24(1): 23-41.

Oheneba-Sakyi, Y. and T.B. Heaton. 1993. "Effects of Socio-demographic Variables on Birth Intervals in Ghana." Journal of Comparative Family Studies 24(1): 113-35.

Ojha, A. 1998. "The Effect of Sex Preference on Fertility in Selected States of India.” The Journal of Family Welfare 44(1): 42-8.

Palloni, A. and H. Rafalimanana. 1994. "The Effects of Infant Mortality on Fertility Revisited: New Evidence from Latin America." Demography 36(1): 41-58.

Rahman, M. and J. Davanzo. 1993. "Gender Preference and Birth Spacing in Matlab, Bangladesh.” Demography 30(3): 315-32.

Rajaram, S., S.R. Rao and A. Pandey. 1994. "Birth Interval Dynamics in Goa: A Parity Specific Analysis." Demography India 23(1-2): 67-81.

RamaRao, S., J. Townsend and I. Askew. 2006. Correlates of Inter-birth Intervals: Implications of Optimal Birth Spacing Strategies in Mozambique. FRONTIERS Final Report March 2006. New York: Population Council.

Richter, K., C. Podhisita, A. Chamratrithirong and K. Soonthorndhada. 1994. "The Impact of Child Care on Fertility in Urban Thailand." Demography 31(4): 651-62.

Rodriguez, G., J. Hobcraft, J. McDonald, J. Menken and J.A. Trussell. 1983. Comparative Analysis of The Determinants of Birth Intervals. Comparative Studies No. 30. London: World Fertility Survey.

Saadeh, R. and D. Benbouzid. 1990. "Breastfeeding and Child-Spacing: Importance of Information Collection for Public Health Policy." Bulletin of the World Health Organization 68(5): 625-31.

Setty-Venugopal, V. and U.D. Upadhyay. 2002. Birth Spacing: Three to Five Saves Lives. Population Reports, Series L, No. 13. Baltimore: Johns Hopkins Bloomberg School of Public Health, Population Information Program.

Suchindran, C.M. and A.L. Adlakha. 1984. "Effect of Infant Mortality on Subsequent Fertility of Women in Jordan: A Life Table Analysis." Journal of Biosocial Science 16(2): 219-29.

Swenson, I. and N.M. Thang. 1993. "Determinants of Birth Intervals in Vietnam: A Hazard Model Analysis." Journal of Tropical Pediatrics 39(3): 163-7.

Teachman, J.D. and D.A. Heckert. 1985. “The Declining Significance of First-Birth Timing.” Demography 22(2): 185-99.

Trussell, J., L.G. Martin, R. Feldman, J.A. Palmore, M.B. Concepcion and D. Abu Bakar. 1985. "Determinants of Birth Interval Length in the Philippines, Malaysia, and Indonesia: A Hazard Model Analysis.” Demography 22(2): 145-68.

Van Houwelingen, J.C. and S. Le Cessie. 1990. "Predictive Value of Statistical Models." Statistics in Medicine 9(11): 1303-25.

World Health Organization. 2006. Report of a WHO Technical Consultation on Birth Spacing. Geneva, June 13-15 2005.

Wyshak, G. 1969. "Intervals between Births in Families Containing One Set of Twins.” Journal of Biosocial Science 1(4): 337-51. 